\title{
Trendy rozwojowe technologii lutowania i metod kontrolnych
}

\author{
Development tendencies of soldering/brazing technology \\ and control methods
}

\section{Streszczenie}

W artykule przedstawiono tendencje rozwojowe lutowania miękkiego i twardego. Zaprezentowano perspektywiczne kierunki oraz obszary badawcze, które w ostatnich latach dynamicznie ewoluowały. Opisano charakterystyki materiałów, których lutowanie jest problematyczne. Udowodniono, że zastosowanie nowoczesnych technik oraz odpowiedni dobór materiałów dodatkowych, umożliwia ich jakościowe wytwarzanie. Przedstawiono rozwój systemów kontrolnych i stopnia zautomatyzowania stanowisk lutowniczych. Wskazano na dynamicznie rozwijające się metody lutowania, proponując przy tym alternatywne źródła ciepła.

Słowa kluczowe: postęp w technologiach lutowania; nowoczesne metody lutowania; jakość złączy lutowanych; automatyzacja lutowania

\begin{abstract}
Development trends of soldering and brazing technologies were presented in this paper. Perspective directions and research areas, which in recent years evolved rapidly, were introduced. Characteristics of materials, which soldering and brazing is problematic, were described and it was proven that use of modern techniques and appropriate selection of additive materials, enables their qualitative manufacture. Development of control systems and automation degree of soldering and brazing stations were presented. Rapidly developing methods of soldering and brazing were pointed out, giving an idea of alternative heat sources.
\end{abstract}

Keywords: advances in brazing/soldering; modern soldering/brazing technologies; quality of soldered/brazed joints; brazing/soldering automation

\section{Wprowadzenie}

Technika lutowania, mimo że znana od kilku tysięcy lat, ciągle dynamicznie się rozwija. Przejawia się to nie tylko w nowych technologiach i materiałach lutowniczych, ale również stale rosnącym potencjale aplikacyjnym. Rosnąca konkurencja wśród wytwórców urządzeń do lutowania powoduje racjonalizację stanowisk lutowniczych, a przez to usprawnienie procesu i złagodzenie reżimów technologicznych. Także stopień zaawansowania technologicznego wytwarzanych aktualnie produktów, często o specyficznych i jednostkowych właściwościach, wymaga stosowania technik zapewniających ich uzyskanie. W takich przypadkach wytwórcy często zwracają się w kierunku lutowania, które umożliwia jakościowe łączenie materiałów radykalnie różniących się składem chemicznym i właściwościami lub pracujących w bardzo odpowiedzialnych rozwiązaniach, niekiedy trudnych warunkach eksploatacyjnych. Posługując się określoną metodą lutowania w połączeniu z doborem konkretnego spoiwa i topnika, można sterować zakresem właściwości złączy, uzyskując żądane charakterystyki, od wytrzymałości mechanicznej, poprzez przewodność cieplną i elektryczną, szczelność, po kompensację naprężeń. Szczególnym wyzwaniem dla technologów są połączenia materiałów różnoimiennych, elementów o zróżnicowanych zależnościach kształtowo-wymiarowych (różniących się znacząco masą/wymiarami lub o złożonej geometrii) czy niemożliwych do spajania


rzalność technologiczną wykonywanych połączeń, przy możliwości usuwania ewentualnych zanieczyszczeń (pozostałości topnikowe), lutowanie staje się realną alternatywą dla innych technik spajania.

Dr inż. Tomasz Piwowarczyk, mgr inż. Ewa Harapińska, dr inż. Tomasz Wojdat - Politechnika Wrocławska.

Autor korespondencyjny/Corresponding author. tomasz.piwowarczyk@pwr.edu.pl 


\section{Kierunki rozwojowe lutowania w świetle analizy literatury i prowadzonych prac badawczych}

Rozwój technologii lutowania przejawia się przede wszystkim w kierunku zwiększania jakości produkowanych połączeń, przy racjonalizacji aspektów ekonomicznych wytwarzania. Analiza tematyki podejmowanej przez uczelnie i ośrodki naukowo-badawcze oraz doświadczenia pracowników firm zajmujących się procesami lutowania pozwala wyselekcjonować kilka obszarów, które kierunkują przyszłość tej techniki $[1 \div 22]$ :

- rozwój i optymalizacja metod lutowania;

- technologie lutowania nowych gatunków materiałów/nowych układów materiałowych, często o niekorzystnym/ skomplikowanym kształcie (folie, struktury plastra miodu);

- rozwój materiałów dodatkowych - lutów i topników (ekologia i ekonomia, przy zachowaniu bardzo dobrej lutowności i właściwości połączeń);

- metody przygotowania powierzchni oraz nanoszenia spoiw i topników (głównie lutowanie miękkie);

- technologie lutowania beztopnikowego;

- modelowanie procesu lutowania;

- automatyzacja i robotyzacja procesów lutowania;

- standaryzacja i normalizacja procesów lutowania;

- nowoczesne metody kontroli jakości połączeń.

Podejmując próbę określenia kierunków rozwoju techniki lutowania na wstępie należy wyraźnie odseparować tendencje dedykowane dla metody lutowania miękkiego i osobno twardego. Techniki te nie różną się jedynie mechanizmem oraz warunkami powstawania złącza, ale przede wszystkim zastosowaniem, wynikającym z różnic $w$ otrzymanych właściwościach. W związku z czym trendy rozwojowe dla obu metod mogą się w szczegółach różnić. W lutowaniu miękkim, często charakteryzującym się produkcją wielkoseryjną, szczególny nacisk położony jest na liczbę wytwarzanych detali w funkcji czasu, przy zapewnieniu poprawnej ich jakości. Aktualne trendy kierunkują tą technikę w stronę łączenia miniaturowych elementów i nakładania nanometrycznych porcji lutu (np. lutowanie chemiczne chemical soldering, nanolitografia thermal dip-pen nanolithography)


sze gabaryty łączonych elementów, a przez to samego złącza, w danej jednostce czasu wytwarza się mniej detali, ale ich jakość zwykle powinna być nienaganna (wysokie i krytyczne wymagania jakościowe).

\section{Rozwój metod lutowania}

Wśród metod lutowania są techniki popularne i często stosowane w procesach wytwórczych (np. lutowanie płomieniowe, indukcyjne, piecowe), ale również mniej znane i rzadziej używane z uwagi na np. większy stopień zaawansowania wyposażenia stanowisk. W przypadku lutowania miękkiego motorem napędowym jest zdecydowanie przemysł elektroniczny. Dla lutowania twardego to przede wszystkim motoryzacja, lotnictwo i kosmonautyka, a także branża wymienników ciepła oraz narzędziowa. Zauważalny w ostatnich latach postęp technologiczny, w zestawieniu z koniecznością łączenia materiałów trudno lutowalnych, często o skomplikowanych kształtach lub niekorzystnych technologicznie wymiarach, spowodował, że zasadniczo wszystkie metody lutowania są rozwijane, ale część z nich w sposób szczególny aktywizuje się na rynku. Są to przede wszystkim $[1,3 \div 14]$ :
Lutowanie mikrofalowe - metoda dedykowana do łączenia ceramiki (np. tlenki glinu, cyrkonu, azotki, węgliki czy diament) z metalami, w którym kontrolowane nagrzewanie z wykorzystaniem promieniowania mikrofalowego pozwala na wyraźną redukcję problemu różnic we właściwościach fizykochemicznych (szczególnie rozszerzalności cieplnej) tych par materiałów.

Lutowanie promieniowaniem podczerwonym - nagrzewanie skoncentrowanym źródłem energii świetlnej (zwykle wysokiej intensywności lampy kwarcowe lub promienniki podczerwieni) ideologicznie zbliżone do lutowania piecowego, ale o zaletach lutowania indukcyjnego. Szczególnie chętnie wykorzystywane do łączenia tytanu i stopów niklu (Hastelloy, Inconel).

Lutowanie elektronowe - realizowane na stanowiskach tożsamych spawaniu elektronowemu, czyli strumień elektronów emitowany jest przez katodę działa w komorze próżniowej, ale wiązka jest bardziej rozproszona, o mniejszej koncentracji w celu zmniejszenia gęstości mocy i uniknięcia nadtopienia materiałów rodzimych. Stosowane głównie do metali i stopów wysoko topliwych, ale również tytanu i ceramiki.

Lutowanie tarciowe "Third-Body Friction Brazing" - technika bazująca na zgrzewaniu tarciowym, w której w wyniku ruchu obrotowego zostaje mocno uplastyczniony dodatkowy (trzeci) materiał łączący - spoiwo o niższej temperaturze topnienia od materiałów rodzimych. Złącza wykazują bardzo dobrą jakość, najczęściej bez naruszenia struktury materiałów łączonych. W ten sposób istnieje możliwość beztopnikowego połączenia np. miedzi i pokrywanej ceramiki z wykorzystaniem lokalnie nagrzewanej tarciowo międzywarstwy w postaci lutu srebrnego.

Lutowanie dyfuzyjne - nisko- $\left(200 \div 700{ }^{\circ} \mathrm{C}\right)$ i wysokotemperaturowa TLP $\left(700 \div 800{ }^{\circ} \mathrm{C}\right)$ technika spajania bazująca na dyfuzji lutu i materiału rodzimego. Spoiwo może być wcześniej naniesione na łączone powierzchnie lub (rzadziej) dozowane z boku. Proces najczęściej realizowany jest w piecach z kontrolowaną atmosferą/próżniowych, a spektrum materiałów łączonych obejmuje wiele metali i ich stopów, gatunków stali, nadstopów czy kompozytów. Co ciekawe, w lutowaniu dyfuzyjnym niskotemperaturowym, w wyniku zjawiska krzepnięcia izotermicznego powstają fazy międzykrystaliczne, o odporności termicznej nawet $2 \div 3$ krotnie wyższej od temperatury topnienia lutu. Technika doczekała się wielu odmian, i tak oprócz ww. metod wyróżnić można również lutowanie dyfuzyjne z izostatycznym dociskiem elementów TLPB, lutowanie dyfuzyjne $w$ niekapilarnych szczelinach LIPB, lutowanie dyfuzyjne $z$ jednoczesnym kształtowaniem $w$ stanie nadplastycznym SPF/B.

Lutowanie/lutospawanie laserowe - skoncentrowana energia źródła laserowego pozwala na zastosowanie metody do materiałów wrażliwych na odkształcenia oraz elementów różniących się zależnościami kształtowo-wymiarowymi, w tym bardzo precyzyjnych lub ograniczanych restrykcyjnymi tolerancjami. Z uwagi na wyraźne zainteresowanie tą techniką branży motoryzacyjnej, często stosuje się ją do łączenia stali (często z pokryciami) z aluminium, ale również możliwe są połączenia różnoimienne ceramiki, stopów lekkich czy materiałów z pamięcią kształtu (NiTi). Coraz częściej wykorzystuje się również technologię trifokal, w której występuje tzw. potrójna plamka - trzy odrębne ogniska (dwa ogniska pomocnicze oraz jedno główne). Ogniska pomocnicze usuwają zanieczyszczenia z powierzchni spajanych oraz wyznaczają granicę płynięcia lutu, a ognisko główne skupione na spoiwie powoduje jego stopienie i płynięcie w granicach wyznaczonych przez ogniska pomocnicze. 
Lutospawanie łukowe - proces wykazujący cechy zarówno lutowania (spoiwo, brak istotnych zmian cieplnych materiałów łączonych), jak i spawania (przygotowanie krawędzi materiałów rodzimych). Może być realizowany elektrodą topliwą (odpowiednik metod MIG/MAG), ale także nietopliwą (TIG) czy coraz częściej plazmą. Wprawdzie lutospawanie gazowe wykazuje aktualnie szerszy potencjał aplikacyjny, ale zaletą metod łukowych jest większa gęstość łuku, przy mniejszych oddziaływaniach temperaturowych i metalurgicznych. Rokująca technika lutospawania plazmowego znajduje zastosowanie do łączenia cienkich blach (karoseryjnych). Jako spoiwo, najczęściej używane są brązy krzemowe, cynowe czy aluminiowe.

Spośród metod lutowania miękkiego dynamicznie rozwijają się metody lutowania rozpływowego i lutowania na fali, dla których prace optymalizacyjne skupiają się na dwóch aspektach $[17 \div 19]$ : materiałowym (luty, topniki, laminaty podłoża, powłoki, podzespoły z wyprowadzeniami) oraz wyposażenia (urządzenia, stanowiska najczęściej zautomatyzowane).

Oczywiście w pozostałych metodach również pojawiają się nowinki technologiczne czy progres związany z wyposażeniem stanowisk, niemniej nie jest on tak wyraźny, jak w przypadku wyżej wymienionych. Przykładem może być zainteresowanie badaczy technikami umożliwiającymi lutowanie złączy o konstrukcji cechujących się szczelinami $>0,5 \mathrm{~mm}$ lub o zmiennej szerokości [4]. Osobną grupą, o której należy wspomnieć jest lutowanie beztopnikowe. Istnieją produkty (np. wymienniki ciepła, źródła mikrofalowe, instalacje radarowe) lub nawet całe gałęzie produktów, do których wytwarzania z uwagi na specyficzne warunki funkcjonalne, nie powinno się stosować agresywnych chemicznie topników [3,4]. Rozwijane są zatem techniki, które pozwalają uzyskać wymaganej jakości złącza, bez ich zastosowania (lutowanie w atmosferach kontrolowanych i próżni, lutowanie lutami samozwilżającymi, lutowanie z mechanicznym usuwaniem tlenków), a tym samym bez wszelkich niedogodności, które powstają podczas lutowania topnikowego $[3,4,6]$. Stosuje się je nawet do materiałów o trwałych warstwach tlenkowych, jak np. aluminium.

\section{Zwiększenie spektrum materiałów łączonych}

Materiały konwencjonalne, jak podstawowe gatunki stali, miedź czy nawet aluminium, nie stwarzają dzisiaj większych trudności podczas lutowania jednoimiennego. Oczywiście optymalizuje się technologie ich spajania, natomiast podstawowe problemy, związane np. ze zwilżalnością powierzchni, zostały już zasadniczo rozwiązane. Jednakże są materiały lub układy materiałowe, dla których ciągle są prowadzone prace badawcze związane z opracowaniem technologii lutowania czy polepszenia jakości złączy lutowanych. Spośród gatunków, które z różnych względów uchodzą za trudno lutowalne wyróżnić można [1 $\div 16,20 \div 22]$ : stopy metali lekkich, stopy niklu i kobaltu, metale trudno topliwe, utwardzane wydzieleniowo stale odporne na korozję, tworzywa ceramiczne (również szkło), kompozytowe i węglowe z metalami czy spieki (pseudostopy, cermetale). Należy tu podkreślić, że największym wyzwaniem jest dzisiaj lutowanie materiałów znacznie różniących się właściwościami fizykochemicznymi, a także bardzo cienkich (np. folie) lub o złożonym kształcie (np. struktura plastra miodu). Analiza aktualnej literatury wskazuje, że często lutowane struktury są zbudowane z kilku materiałów tworząc wielostopniowe konfiguracje przekładkowe $[1,2,9 \div 14]$. W przypadku kompozytów, spieków czy wyprasek, badacze podkreślają negatywne oddziaływanie ewentualnych porowatości, które mogą być dopuszczalne z punktu widzenia technologii wytwarzania czy funkcjonalności elementu, natomiast niekorzystnie wpływają na przebieg lutowania. Uwalniana podczas procesu faza gazowa utlenia powierzchnie elementów łączonych znacznie pogarszając ich zwilżalność ciekłym lutem.

\section{Rozwój materiałów dodatkowych}

Wśród wielu aspektów rozwojowych techniki lutowania należy wspomnieć o pojawiających się na rynku nowych spoiwach i topnikach, przewyższających swoimi charakterystykami dotychczas stosowane materiały dodatkowe. W przypadku lutów dominują działania w kierunku opracowania nowych stopów, ale często obserwuje się również produkty o nieznacznie zmodyfikowanym składzie chemicznym w stosunku do znanych produktów, jednak korzystniejszych właściwościach lub bardziej użytecznej postaci. Spoiwa nie tylko powinny spełniać założone wymagania technologiczne (zwilżalność, rozpływność, kapilarność, temp. aktywności itp.), ale wykazywać przy tym wymagane charakterystyki mechaniczne (wytrzymałość, plastyczność). W ostatnich latach zauważalne jest w niektórych gałęziach przemysłu (chłodnictwo, klimatyzacja) wypieranie lutów twardych przez miękkie. Spowodowane jest to opracowaniem nowej gamy wysokowytrzymałych spoiw o niskich temperaturach topnienia, które nie obciążają cieplnie materiałów rodzimych, zachowując ich parametry użytkowe. Radykalna zmiana dotknęła również skalę kontroli wytopu stopów lutowniczych. Najwięksi wytwórcy spoiw są $w$ stanie wydać swoim głównym klientom pisemną gwarancję stabilności zakresu temperaturowego topnienia lutów, niezależnie od partii wyrobu. Jest to szczególnie istotne podczas lutowania na stanowiskach zautomatyzowanych, gdzie ścisła kontrola temperatury wpływa na wskaźniki jakościowe produkcji. Zauważalny jest również istotny z przemysłowego punktu widzenia akcent ekonomiczny. Producenci przygotowują produkty o obniżonej zawartości kosztownych pierwiastków (np. srebro), ale oferujących identyczne parametry użytkowe, jak ich droższe odpowiedniki. Różnice te często sięgają $>10 \%$. To nie tylko wymierna oszczędność ekonomiczna, ale również większa swoboda planowania i mniejsza zależność od wahań cen metali szlachetnych. Dyskutowany jest również korzystny wpływ tzw. aktywatorów (niewielkie domieszki wybranych pierwiastków, np. V, Ti, Mo, metale ziem rzadkich), poprawiających zwilżalność i rozpływność ciekłych lutów oraz właściwości złączy [4]. Z uwagi na niewielką popularność nowością są wciąż stosowane w agresywnych środowiskach luty niemetaliczne: ceramiczne czy szklane [1]. Zasadniczo każdy producent oferuje dzisiaj postać lutu dopasowaną do potrzeb klienta (pasty, szpule, pręty, kształtki), ze spoiwami rdzeniowymi czy otulonymi włącznie. Zaawansowane systemy wytwórcze sięgają dzisiaj po luty bazujące na spoiwie o ziarnistości nanometrycznej, bardzo cienkie luty w postaci taśm i folii, a nawet luty o budowie kompozytowej (np. luty przekładkowe z wełną stalową czy wysokotemperaturowe luty aktywne $z$ węglikami) $[1,2,9 \div 14]$.

W przypadku topników obserwuje się działania ukierunkowane na sterowanie zakresem temperaturowym (szerokim w przypadku produktów uniwersalnych i bardzo wąskim dla produkcji dedykowanej) oraz próby opracowania receptur eliminujących oczyszczanie złącza po lutowaniu (np. tworzące łatwo usuwalny niekorozyjny 
żużel potopnikowy, topniki no-clean). Oferta niehigroskopijnych topników niekorozyjnych, występujących często bez substancji wiążących jest aktualnie stale poszerzana. Ciekawym rozwiązaniem praktycznym jest występowanie danego topnika w kilku wersjach, nieznacznie różniących się zawartością pojedynczego pierwiastka, co przekłada się na zmianę jednej z właściwości, istotnej z technologicznego punktu widzenia. Przykładem mogą być spoiwa rdzeniowe dopasowane np. pod względem rzadkopłynności do szerokości szczeliny oraz założonej prędkości przesuwu taśmy pieca, bez konieczności zmian nastaw temperatury w poszczególnych jego strefach. Podobnie projektowane są topniki do łączenia w wymuszonych pozycjach. Innym zastosowaniem są topniki o rozszerzonym czasie aktywności, dedykowane do wielkogabarytowych elementów spajanych. Ciągle popularne są topniki w postaci lotnej.

Od momentu wprowadzenia dyrektywy RoHS, mającej na celu zmniejszenie ilości substancji niebezpiecznych przenikających do środowiska z odpadów elektrycznych i elektronicznych, w branży lutowniczej zaobserwowano widoczne trendy proekologiczne. Obecnie stosowanie spoiw bez dodatków ołowiu czy kadmu jest w zasadzie standardem. Na tym jednak dążenia producentów materiałów dodatkowych do lutowania w aspekcie wytwarzania i sprzedaży produktów ekologicznych się nie ograniczyły, dzięki czemu na rynku pojawia się coraz więcej lutów i topników określanych liniami eco, green, free itp. Przyczyniło się do tego również rozporządzenie RE$\mathrm{ACH}$ (ang. Registration, Evaluation and Authorisation of Chemicals) regulujące kwestie stosowania substancji chemicznych, a mające na celu zapewnienie wysokiego poziomu ochrony zdrowia i środowiska. Wychodząc naprzeciw aktualnym, ale również przewidywanym przyszłym przepisom obowiązującym w sektorze lutowania, firmy pracują nad gamą innowacyjnych produktów niewykazujących właściwości rakotwórczych czy mutagennych. W przypadku spoiw tendencje ukierunkowane są na rozwój produktów zawierających jedynie pierwiastki, które nie powodują szkodliwego działania na środowisko naturalne. Alternatywą dla stosowanych powszechnie lutów SnPb są niestety spoiwa o wyższych temperaturach topnienia oraz większym napięciu powierzchniowym, spośród których najpopularniejsze gatunki to: SnAg, SnCu,

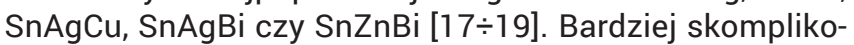
wana sytuacja jest w przypadku topników, które w większości przypadków bazują na potencjalnie nieobojętnych, a w skrajnych przypadkach niebezpiecznych dla zdrowia związkach chemicznych. Zatem znalezienie proekologicznych substytutów często jest bardzo trudne. Dodatkowo sytuację komplikują kontrowersyjne zapisy w regulacjach prawnych, które dopuszczają do obrotu bezsprzecznie szkodliwe, a czasami nawet trujące substancje (np. kwas solny, kwas fluorowodorowy, wodorotlenek sodu), a produkty uchodzące do niedawna za nieszkodliwe (np. boraks, kwas borowy) sugerują wycofywać (rozporządzenie EC 1907/2006-REACH). Konkretne przypadki ograniczenia stosowania uwodnionego boranu sodu i kwasu borowego tłumaczy się zakwalifikowaniem tych substancji do 2 kategorii obejmującej związki chemiczne o działaniu szkodliwym na rozrodczość. Z tego też względu większość producentów, chcąc nadążać za aktualnymi wymogami prawnymi, prowadzi szereg badań nad topnikami eliminującymi czy też ograniczającymi procentowy udział związków toksycznych, korozyjnych i drażniących w ich składach recepturowych. Boraks i kwas borowy zastępuje się związkami boru wyższego rzędu, które nie są toksyczne i nie działają drażniąco, takimi jak np. fluoroboran potasu. Równie istotne jest nieprzekraczanie określonych poziomów ilościowej skali kwasowości i zasadowości pH. Stąd oprócz wyżej wymienionych produktów unika się chlorku cynku, alkoholu metylowego (aktualnie rzadko stosowanego, zastępowanego alkoholem etylowym lub acetonem) i wielu innych dotychczas powszechnie stosowanych substancji. W montażu bezołowiowym zmiana składu chemicznego spoiw pociągnęła za sobą konieczność opracowania nowych receptur topników, na bazie żywic i aktywatorów o zwiększonej aktywności oraz zakresie temperaturowym. Popularne stały się topniki VOC-free (Volatile Organic Compounds) nie zawierające lotnych związków organicznych [18]. Modyfikacji uległy również sposoby ich aplikowania. Dodatkowo nowoczesne topniki do lutowania twardego wykazują cechy poprawiające właściwość i efektywność ich stosowania, np. zmiana barwy po osiągnięciu temperatury aktywności.

\section{Alternatywne gazowe źródła ciepła}

W ostatnich latach wyraźnie można dostrzec zainteresowanie alternatywnymi gazami do lutowania. Szczególnie perspektywiczne wydaje się zastosowanie mieszanek z wodorem. Wprawdzie generatory tlenu i wodoru są urządzeniami znanymi od dłuższego czasu, jednak dopiero niedawno osiągnęły wydajności umożliwiające zastosowanie produkcyjne. Udało się nawet skonstruować jednostki obsługujące jednocześnie kilka stanowisk, z których każde może pracować na innych parametrach i wydatkach. Producenci generatorów zapewniają, że zastosowanie ich rozwiązań umożliwia [23]: lepsze płynięcie i penetrację lutu, mniejsze utlenianie materiału, mniejszą ilość zanieczyszczeń wewnątrz materiału, około $2 \div 3$ razy większą prędkość lutowania oraz obniżenie kosztów produkcji nawet do $80 \div 85 \%$. Dodatkową zaletą jest brak konieczności magazynowania i wymiany butli gazowych (jak w przypadku propanu, tlenu czy acetylenu). Niebagatelne są również aspekty ekologiczne - w wyniku procesu hydrolizy wody efektem spalania jest para wodna.

Istnieje również alternatywna koncepcja, bazująca na połączeniu wybranego nietradycyjnego gazu palnego z odpowiednim oprzyrządowaniem. Wyróżnia ją korzystny wskaźnik ekonomiczny, wygoda stosowania, lepsze osiągi oraz bezpieczeństwo użytkowania. Wykorzystanie specjalnej konstrukcji mikserów inżektorowych, umożliwia zasysanie precyzyjnej porcji gazu palnego, w celu zapewnienia maksymalnej wydajności turbulentnej mieszanki. Zastosowanie tradycyjnego palnika w połączeniu z wybranym gazem alternatywnym (propylen, propan, gaz ziemny, autorskie mieszanki dostawców gazów), nie pozwala uzyskać ww. zalet, gdyż instalacja dedykowana do acetylenu pracuje na innych parametrach roboczych. Aktualnie pojawiają się na rynku sterowane cyfrowo rozwiązania, będące integracją dokładnych urządzeń dozujących oraz oprogramowania analizującego właściwości mieszanki, a nawet wyliczającego oszczędności.

\section{Rozwój metod kontrolnych}

Istotę zagadnienia jakości połączeń lutowanych pokazuje historia najnowsza. W największym na świecie akceleratorze cząstek Wielkim Zderzaczu Hadronów, znajdującym się w CERNie wykonano przez 4 lata ok. 52 miliony połączeń lutowanych [24]. Część złączy była niepoprawna (naj- 
częściej niewłaściwy kontakt prądowy), ale usterki te były na bieżąco monitorowane i korygowane. Natomiast zwarcie w jednym połączeniu elektrycznym doprowadziło w $2008 \mathrm{r}$. do awarii, generując koszty naprawy w wysokości 21 milionów dolarów.

Zgodnie z ideą procesów lutowania, stosuje się w nich materiały dodatkowe różniące się właściwościami fizycznymi od materiału podstawowego, zatem założenia technik kontrolnych muszą bazować na innych charakterystykach badawczych. Dlatego też kontrola jakości takich połączeń, którą standardowo wykonuje się w sposób niszczący oraz nieniszczący, należy do zagadnień bardziej złożonych. Wytyczne przeprowadzania metod niszczących badań połączeń wykonanych w procesie lutowania twardego zostały opisane w PN-EN 12797:2002. Scharakteryzowano w niej zasady badania wytrzymałości na ścinanie, rozciąganie, próby twardości, odrywania i zginania oraz badań metalograficznych. Ponadto określono kształt i wymiary próbek badanych, opis sposobu przeprowadzania badań oraz treści wymagane w protokole badania. W przypadku badań niszczących nie zauważa się tendencji rozwojowej w rozumieniu powstania nowych metod i zasad ich przeprowadzania. Ewentualnie modyfikuje się już znane metody lub opracowuje nowe próby technologiczne, najczęściej stanowiskowe, dedykowane do konkretnych rozwiązań konstrukcyjnych złączy.

Aktualnie największe znaczenie w analizie złączy lutowanych mają badania nieniszczące, które są systematycznie rozwijane o nowe technologie. W PN-EN 12799:2003 opisano konwencjonalne metody kontroli, a także rodzaje złączy próbnych. Połączenia lutowane można badać w sposób nieniszczący w aspekcie trzech głównych kierunków: ze względu na wytrzymałość mechaniczną, przewodność elektryczną, a także szczelność. Po wykonaniu badań wizualnych, które są obligatoryjne bez względu na przedmiot badania, można wykonać cały wachlarz badań uzupełniających. Bardzo często wykorzystuje się w tym celu badania penetracyjne (również fluorescencyjne dla uzyskania lepszego kontrastu), radiograficzne i ultradźwiękowe, ale również metody wykorzystujące transfer ciepła, emisję akustyczną czy holografię [3].

W przemyśle elektronicznym stosuje się przede wszystkim badania przewodności elektrycznej. Najczęściej ograniczają się one do systemu wizyjnego, który porównuje wybrane strefy na PCB do wzorca. Złącza wykonane za pomocą technik SMT i THT nie muszą być poddawane testom wytrzymałościowym, ponieważ w teorii po zamontowaniu w obudowę elementy nie są poddawane obciążeniom mechanicznym. Ciekawym przykładem jest badanie połączeń stali niestopowej ze stopem z pamięcią kształtu NiTi, przeprowadzane z wykorzystaniem metody prądów wirowych [25]. Na podstawie otrzymanych charakterystyk impedancji w funkcji odległości, łatwo rozpoznać gdzie rozpoczyna się połączenie - otrzymując znaczny wzrost wartości impedancji. Równocześnie kontroler jest w stanie określić objętość lutu wykorzystaną do wykonania połączenia.

Osobną grupą zagadnień są różnorodne procesy lutowania wymienników ciepła. Ze względu na ich skomplikowaną geometrię, związaną bezpośrednio ze sprawnością odprowadzania ciepła, a także niejednokrotnie występujące połączenia różnoimienne, już sam proces lutowania bywa trudny. Podobnie jest $z$ analizą jakości wykonanych połączeń, w której bardzo chętnie wykorzystuje się badania radiograficzne, co aktualnie nie stanowi nowości w nieniszczących technikach kontrolnych. Inaczej jednak niż parę lat temu wygląda kwestia oceny radiogramów.
Przede wszystkim aktualne systemy coraz częściej działają w sposób całkowicie zautomatyzowany. Całość sprowadza się do typowej analizy obrazu, gdzie w celu identyfikacji poprawności wykonanych połączeń najczęściej stosuje się funkcję wyrównania histogramu (rozkładu pikseli w skali odcieni szarości) [26]. Metodyka bazuje na korekcie kontrastu zdjęcia w oparciu o histogram, a tym samym jednoznacznym odróżnieniu szumu od niezgodności. Kolejną przydatną operacją, którą można wykorzystać do automatycznego określania zgodności połączeń jest progowanie. Polega ono na pogrupowaniu pikseli obrazu najczęściej na dwa obszary. Działanie to pozwala na osiągnięcie dużego kontrastu pomiędzy obszarem wymiennika ciepła a pustkami, które mogą oznaczać zarówno światło przewodu doprowadzającego medium, jak i obszary nie do końca wypełnione lutem. Trzecia z najczęściej stosowanych metod wykorzystuje algorytm wykrywania krawędzi Canny'ego. Technika ta polega na bardzo precyzyjnym określeniu występowania krawędzi pomiędzy dwoma grupami kolorów, dzięki czemu w relatywnie krótkim czasie można dokonać analizy radiogramu danego elementu lutowanego. W tym przypadku nie ma możliwości uzyskania podwójnej krawędzi, co występuje bardzo często podczas wykrywania innymi metodami.

Problematycznym zagadnieniem może być prowadzenie badań ultradźwiękowych złączy lutowanych. Połącznie składać się może z trzech materiałów o zróżnicowanych właściwościach fizycznych, zatem nie jest łatwe dokonanie oceny jego jakości techniką bazującą na określonych charakterystykach materiałowych. Najważniejszym aspektem jest fakt, że badania ultradźwiękowe należą do grupy kontaktowych, zatem dopasowanie głowicy musi być odpowiednie do kształtu badanych elementów. W innym przypadku sprzężenie akustyczne pomiędzy głowicą, a materiałem będzie co najmniej niewystarczające, tym bardziej jeśli trzeba dokonać oceny niezgodności [27]. Wskazania będą się również zmieniać w zależności od technologii przygotowania złącza - fala ultradźwiękowa inaczej będzie się propagować w ośrodku z płynnym przejściem faz (dyfuzja - lutowanie twarde), inaczej natomiast w przypadku połączeń czysto adhezyjnych (lutowanie miękkie).

Szerokie pole zastosowań w ocenie złączy lutowanych oferuje termografia aktywna. Istnieją techniki badawcze wykorzystujące zmiany charakterystyk podczas nagrzewania złącza [28], ale również takie, w których elementy najpierw się schładza (np. w ciekłym azocie), a następnie poddaje kąpieli (np. w wodzie) o podwyższonej temperaturze [29]. Działania te mają na celu uzyskanie jak najwyższego gradientu temperaturowego, co bezpośrednio wpływa na bardzo dobry kontrast końcowego obrazu.

\section{Rozwój stopnia zautomatyzowania stanowisk lutowniczych}

Lutowanie przemysłowe w znacznej części realizowane jest na stanowiskach zmechanizowanych, zautomatyzowanych, a w ostatnich latach coraz częściej zrobotyzowanych. Ograniczenie wpływu czynnika ludzkiego, pozwala na osiągnięcie wielu korzyści, które można podzielić na trzy główne grupy: technologiczne, ekonomiczne i organizacyjne. Całość docelowo prowadzi do redukcji kosztów, eliminacji braków oraz poprawy jakości wykonywanych połączeń, wpisując się w priorytety działań konkurencyjnego przedsiębiorstwa. Do podstawowych zalet automatyzacji stanowisk lutowniczych należą: racjona- 
lizacja wykorzystania możliwości produkcyjnych, optymalizacja zużycia materiałów dodatkowych, zapewnienie wysokiego poziomu jakości wytwarzania przy zachowaniu stabilności procesowej oraz zwiększenie wydajności przy minimalizacji czasów wytwórczych. Istotny jest również czynnik związany z bezpieczeństwem i higieną pracy oraz kosztami. Realizowane jest to głównie na poziomie wykonawstwa i sterowania, ale coraz częściej również kontroli operacji technologicznych.

Zasadność automatyzacji procesu lutowania należy zweryfikować uwzględniając następujące czynniki [3]: rachunek ekonomiczny; podział procesu na etapy i ustalenie, które z nich będą automatyzowane, które pozostaną ręczne, a które w ogóle można wyeliminować; określenie zapotrzebowania na zautomatyzowane doposażenie stanowiska; wskazanie konieczności uzupełnienia wiedzy z zakresu planowanych zmian, zarówno od strony technologicznej, jak i obsługi parku maszynowego. Wymienione czynniki są determinowane przez aspekty praktyczne procesu lutowania, z których najistotniejsze to: gatunek materiałów rodzimych (właściwości), charakterystyki materiałów dodatkowych (luty i topniki), wymagania stawiane złączom (wytrzymałość, przewodność elektryczna, odporność temperaturowa itp.), ewentualnie wymagana struktura połączeń [3].

W pełni zautomatyzowane systemy dominują podczas lutowania miękkiego. Lutowanie metodą fali stojącej (pojedynczej lub podwójnej, z topnikowaniem zraszającym kompleksowym lub selektywnym) i selektywne na fali stacjonarnej, są zasadniczo procesami całkowicie bezobsługowymi $[17 \div 19]$. Podobnie procesy lutowania rozpływowego w parach nasyconych, w podczerwieni, w warunkach konwekcji naturalnej czy wymuszonej $[17 \div 19]$. W lutowaniu miękkim opracowano wiele sposobów aplikacji lutu, od klasycznych

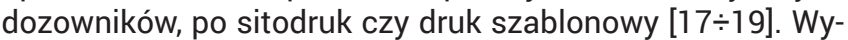
mienione zautomatyzowane metody lutowania miękkiego stosowane są przede wszystkim w przemyśle elektronicznym (obwody drukowane) i elektrotechnicznym, lutowaniu wymienników ciepła (np. chłodnic samochodowych) i drobnej galanterii.

Stanowiska lutownicze mogą się znacznie różnić w zależności od stopnia zautomatyzowania procesu wytwórczego. Podstawowe rozwiązania zmechanizowane stanowią wsparcie dla procesów ręcznych, w postaci np. urządzeń dozujących, umożliwiających szybką i precyzyjną aplikację pasty lutowniczej, zapewniając powtarzalność kształtu i objętości spoiwa. Funkcje te mogą pełnić również dozowniki sprzężone z manipulatorami, ale wtedy często nieodzowny jest dodatkowy kontrolny system optyczny. Kolejnym stadium są częściowo zautomatyzowane stacje lutownicze. W zależności od profilu produkcji wspomagane mogą być różne moduły: nagrzewania, dozowania spoiwa, chłodzenia czy podawania elementów. Rola operatora ograniczona jest zwykle do wykonywania jednej czynności, najczęściej montażu/demontażu detali. W przypadku specyficznych konstrukcyjnie złączy, gdzie nie ma możliwości zastosowania past lutowniczych, mechanizuje się podawanie spoiwa w postaci drutów/prętów litych. Dedykowane stacje lutownicze dzieli się zwykle w zależności od wielkości produkcji (np. kilkadziesiąt elementów na godzinę = stanowisko niskoprodukcyjne). Spośród metod lutowania twardego, na ogół mechanizacja towarzyszy procesom nagrzewania płomieniowego (palniki o sterowanych cyklach pracy), natomiast w lutowaniu indukcyjnym i piecowym kontrol je się temperaturę w poszczególnych etapach łączenia [1]. Łączone elementy często dostarczane są w systemach taśmowych, podziałowych, przenośnikowych lub z wykorzystaniem obrotników/karuzel. Końcowym etapem procesu na zmechanizowanych/zautomatyzowanych stanowiskach często jest usuwanie powstałych zanieczyszczeń w postaci pozostałości potopnikowych itp. (nowoczesne systemy ultradźwiękowe [3]).

Większe zakłady obejmujące zakresem wytwórczym lutowanie obszernej gamy elementów, lub nawet podobnych detali, ale różniących się nieznacznie zależnościami kształtowo-wymiarowymi, chętnie modyfikują stanowiska wprowadzając tzw. elastyczne systemy produkcyjne. Są to rozwiązania zdolne do produkcji szerokiego asortymentu wyrobów, ale przede wszystkim możliwości zmiany profilu produkcji, w aspekcie reakcji na nowe zamówienia i projekty wytwórcze.

Należy tu podkreślić, że aktualnie większość nowoczesnych stanowisk lutowniczych jest układami mechatronicznymi, zawierającymi część mechaniczną w postaci napędu i elementów wykonawczych, najczęściej sterowaną elektronicznym układem mikroprocesorowym, sprzężonym z odpowiednim oprogramowaniem. Każdy z poszczególnych układów (mechaniczny, elektroniczny, sterowanie i oprogramowanie) jest rozwijany indywidualnie w celu osiągnięcia optymalnych charakterystyk całego systemu. Dodatkowo wytwarzane obecnie struktury zautomatyzowane cechuje coraz większa modułowość i otwarta architektura.

\section{Podsumowanie}

Zalety lutowania, które predestynują tą technikę do zastosowań przemysłowych, a tym samym sprawiają, że jest ona stale rozwijana to przede wszystkim: możliwość łączenia w jednej operacji wielu elementów o zróżnicowanych kształtach i wymiarach, gwarancja spełnienia uwarunkowań metalurgiczno-technologicznych oraz duża różnorodność rozwiązań konstrukcyjnych. Omówione w artykule kierunki rozwoju techniki lutowania, niezależnie od tego czy dotyczą metod, materiałów dodatkowych czy stopnia zautomatyzowania, mają docelowo prowadzić do możliwości uzyskania złączy o bardzo dobrej jakości, poprawy wydajności stanowisk i obniżenia kosztów wytwarzania. Obserwowane trendy orientują się zarówno w stronę optymalizacji istniejących systemów wytwórczych, jak i projektowania zupełnie nowych technologii. Towarzyszy temu ciągła standaryzacja i normalizacja - od początku 2010 r. PKN opublikował kilkadziesiąt aktualnych norm obejmujących swoim zakresem prace lutownicze. Doświadczenie zawodowe autorów nie pozwala na przygotowanie publikacji bazującej jedyne na doświadczeniach własnych, stąd niniejsze opracowanie stanowi syntezę doświadczeń badaczy i pracowników naukowych zajmujących się techniką lutowania. 


\section{Literatura}

[1] J. Nowacki, M. Chudziński, P. Zmitrowicz: Lutowanie w budowie maszyn, WNT, Warszawa 2007

[2] Z. Mirski: Sterowanie szerokością szczeliny lutowniczej w procesach spajania materiałów różnoimiennych, Oficyna Wydawnicza PWr, Wrocław 2000.

[3] M. Schwarz: Brazing, Second edition, ASM International, Ohio 2003.

[4] D.M. Jacobson, G. Humpston, Principles of Brazing, ASM International, Ohio 2005.

[5] R. Radtke, J. Geddes: Microwave brazing, a novel method for joining ceramics to metals, Fourth World Congress on Microwave and Radio Frequency Applications, Austin, Texas 2004

[6] J. Pilarczyk (red.): Poradnik Inżyniera, Spawalnictwo, tom 2, WNT, Warszawa 2005.

[7] J. Wojewoda: Lutowanie dyfuzyjne niskotemperaturowe nowa technika spajania zaawansowanych materiałów, projekt badawczy Nr TO8C 02 829, IMIM PAN, Kraków 2008.

[8] Z. Mirski, K. Granat, S. Stano: Possibilities of laser-beam joining cemented carbides to steel, Welding International, $\mathrm{nr} 3$ (30)/2016.

[9] Brazing, High Temperature Brazing und Diffusion Bonding, LÖT 2013, Lectures and posters of the 10th International Conference Aachen June 2013, DVS Media, Düsseldorf 2013.

[10] High Temperature Brazing and Diffusion Bonding, LÖT 2016, Lectures and posters of the 11 th International Conference Aachen June 2016, DVS Media, Düsseldorf 2016

[11] S. Weis, G. Wagner, B. Wielage: Brazing technology - Advances and challenges, International Brazing \& Soldering Conference (IBSC), Long Beach 2015.

[12] D.P. Sekulić (ed.): Advances in Brazing, Science, technology and application, Woodhead Publishing, 2013.

[13] R. Gourley, Ch. Walker (ed.): Brazing and Soldering - Proceedings of the 5th International Brazing and Soldering Conference, Las Vegas 2012.

[14] Brazing Handbook, American Welding Society Committee on Brazing and Soldering, Fifth Edition, Miami 2007.

[15] M. Baranowski, J. Jakubowski: Lutowność wybranych nadstopów niklu, Przegląd Spawalnictwa, nr 7 (86), 2014.
[16] T. Babul, A. Kondej, S. Kowalski, M. Baranowski, K. Lankiewicz: Wpływ obróbki powierzchniowej na lutowność stali 410, Przegląd Spawalnictwa, nr 3 (88), 2016.

[17] J. Felba: Montaż w elektronice, Oficyna Wydawnicza Politechniki Wrocławskiej, Wrocław 2010

[18] K. Bukat, H. Hackiewicz: Lutowanie bezołowiowe, Wyd. BTC, Warszawa 2007.

[19] M. Schwartz: Soldering - Understanding the Basics, ASM International, Ohio 2014.

[20] A. Winiowski, D. Majewski: Lutowanie twarde stopów magnezu, Przegląd Spawalnictwa, nr 12 (86), 2014

[21] Z. Mirski, D. Majewski: Lutowność tytanu w warunkach płomieniowego lutowania twardego pod osłoną topnika, Przegląd Spawalnictwa, nr 1 (85)/2013.

[22] Z. Mirski, M. Różański: Lutowanie próżniowe tytanu technicznego i stopu tytanu na osnowie fazy TiAl (Y), Inżynieria Materiałowa, nr 4 (33)/2012.

[23] R. Lewandowski, Profesjonalne urządzenia do lutowania i podgrzewania za pomocą tlenu i wodoru, opracowanie Rywal-RHC.

[24] LHC Deliveries Success/Failure Statistics Report 2004-2012, CAEN, Report nr. 22, 2012

[25] T. G. Santos, F. B. Fernantes, G. Bernardo, R. M. Miranda: Analyzing mechanical properties and nondestructive characteristic of brazed joints of NiTi shape memory alloys to carbon steel rods, The International Journal of Advanced Manufacturing Technology, nr 66, Londyn 2013.

[26] J.Y. Kim, S.-W. Seo: Inspection of brazing joint defects in the heat exchanger using X-ray, International Conference on Control, Automation and Systems, Gyeonggi-do 2010.

[27] A. Łosieczka, L. Sozański: Wybrane aspekty badań ultradźwiękowych miedzianych połączeń lutowanych, Przegląd Spawalnictwa, nr 9 (82), 2010.

[28] S. Pawlak, M. Różański, G. Muzia: Zastosowanie termografii aktywnej do badań nieniszczących połączeń lutowanych, Przegląd Spawalnictwa, nr 2 (85), 2013.

[29] P. Chaudhuri, P. Santra, S. Yoele, A. Prakash, D.C. Reddy, L.T. Lachhvani, J. Govindarajan, Y.C. Saxena: Non-destructive evaluation of brazed joints between cooling tube and heat sink by IR thermography and its verification using FE analysis, NDT\&E International, nr 39, 2006. 